\title{
Photodynamic therapy as an aiding in the endodontic treatment: case report
}

\author{
Terapia fotodinâmica em Endodontia: \\ relato de caso
}

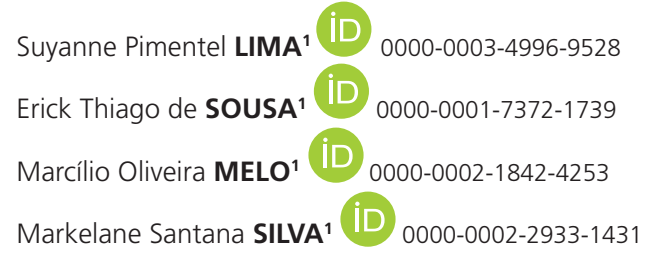

\section{ABSTRACT}

This article describes the application of Photodynamic Therapy as an aid to the endodontic treatment performed on a permanent tooth iatrogenically perforated and with pulp necrosis. After clinical and radiographic examination, the coronary access, curettage of the drilling area and mechanized preparation with the Reciproc System were performed. The drilling area was sealed with Mineral Trioxide Aggregate after prior alkalinization and decontamination by a calcium hydroxide buffer. After successive intracanal medication changes, the remission of the fistula, a clinical sign of endodontic infection, was not observed. Photodynamic therapy was then performed to reduce bacterial load in the root canal system, which resulted in fistula suppression. Then, it was possible to end the treatment with the obturation of the ducts by the Tagger Hybrid thermomechanical technique. After a year of proservation, the tooth presents no symptomatology and it is concluded that the Photodynamic Therapy was an effective solution in this case.

Indexing terms: Dental fistula. Endodontics. Photochemotherapy.

\section{RESUMO}

Neste artigo descreve-se a aplicação da Terapia Fotodinâmica (PDT) como coadjuvante ao tratamento endodôntico realizado em dente permanente perfurado iatrogenicamente e portador de necrose pulpar. Após exame clínico e radiográfico, realizou-se a abertura coronária, curetagem da área da perfuração e preparo mecanizado com o sistema Reciproc (VDWIAlemanha). A área da perfuração foi selada com agregado trióxido mineral (MTA) depois de prévia alcalinização e descontaminação por um tampão de hidróxido de cálcio (HC). Após sucessivas trocas de medicação intracanal (MI) a fístula, sinal clínico de infeção endodôntica, não desaparecia. A terapia fotodinâmica então foi executada para reduzir a carga bacteriana do sistema de canais radiculares (SCR), o que resultou na remissão da fístula, propiciando a finalização do tratamento, com a obturação dos condutos pela técnica termomecânica Híbrida de Tagger e sucesso clínico com 1 ano de proservação.

Termos de indexação: Fístula dentária. Endodontia. Fotoquimioterapia.

$\operatorname{rrr}$

1 Associação Brasileira de Odontologia -Secção Piauí. Rua Dr. Area Leão, 545, Centro, 64001-310, Teresina, PI, Brasil. Correspondência para / Correspondence to: MS SILVA. E-mail: <markelanesantanasilva@gmail.com>.

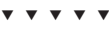

How to cite this article

Lima SP, Sousa ET, Melo MO, Silva MS. Photodynamic therapy as an aiding in the endodontic treatment: case report. RGO, Rev Gaúch Odontol. 2019;67:e20190030. http://dx.doi.org/10.1590/1981-86372019000303583 


\section{INTRODUCTION}

The current endodontic techniques are not yet able to remove all the bacteria from the Complex Root Canal System (RCS), which makes it difficult to completely remove the microorganisms and thus, bacterial persistence can occur after treatment [1,2,]. The removal of microorganisms remaining from RCS and the prevention of subsequent reinfection are the most important objectives in the success of endodontic treatment [3].

The failures in conventional endodontic treatment are related to residual and permanent infections, which require additional strategies for disinfection [4]. Recently, the limitations of conventional endodontic therapy have given rise to many attempts to introduce Photodynamic Therapy (PDT) as an alternative treatment [5].

PDT has been suggested as a promising adjuvant therapy in the treatment of endodontic infection [6]. The term was first reported in the medical literature in 1941, defined as a reaction between photosensitizers and light, generating cytotoxic effect through oxidative reactions [4]. PDT does not have serious side effects and can be repeated frequently. It destroys cells by necrosis or apoptosis and can be used for localized destruction of living tissue with abnormal growth [7].

During PDT, a non-toxic photosensitizer (dye) placed directly at the destination site can be activated by means of an appropriate wavelength of visible light that causes damage to microbial components [8-10]. The transfer of energy from the activated photosensitizer to the available oxygen results in the formation of toxic oxygen species, known as singlet oxygen and free radicals, which are highly reactive and damage proteins, lipids, nucleic acids and other cellular microbial components [1,11-13].

The objective of this work is to describe the clinical case of an endodontic treatment in an iatrogenic perforated tooth to which the Photodynamic Therapy was used to contain the persistent infection.

\section{CASE REPORT}

A 16-year-old male patient presented to the Endodontics clinic of the Brazilian Dental Association - Piauí section (Associação Brasileira de Odontologia - secção Piauí - ABO-PI), with clinical picture of intraoral edema, palpation pain and extensive iatrogenic perforation in the mesial wall of the tooth 26 associated with vestibular fistula (figure 1).

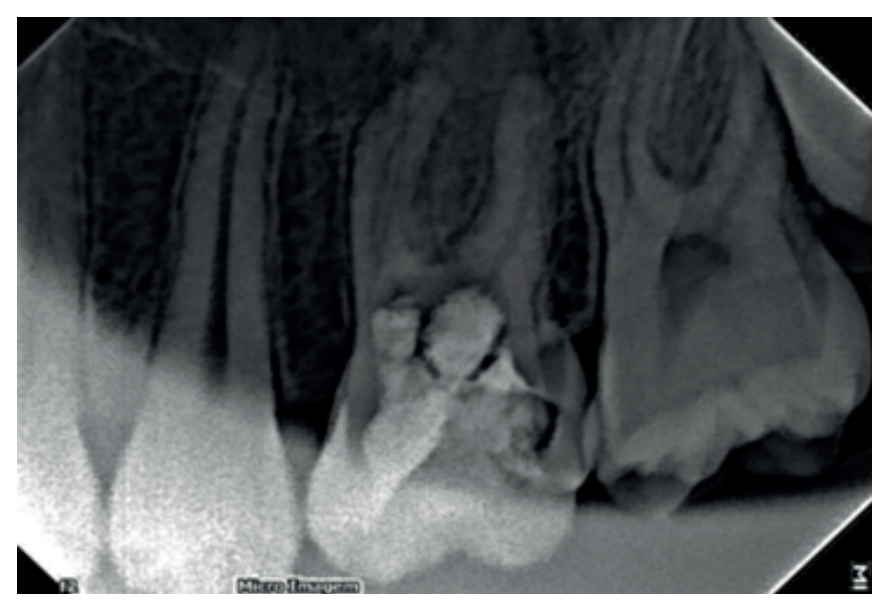

Figure 1. Initial radiographic appearance of the tooth 26.

During the anamnesis, the patient previously reported having undergone an emergency intervention in this tooth by another professional due to acute pain characteristic of pulpitis. The tooth was then submitted to endodontic intervention in which coronary access was performed and pulp necrosis and presence of perforation were clinically verified.

The area of the perforation was cured to remove the granulation tissue and later covered by a calcium hydroxide buffer $(\mathrm{CH})$ in the pro-analysis form (PA) for the purpose of decontamination of the infected area, favoring the process of beginning the formation of the sealing of the region.

In the same session, crown-down instrumentation was performed using chorexidine gel $2 \%(\mathrm{CHX})$ and saline solution $0.9 \%$ as the chemical solutions. Odontometry was determined using the foraminifera locator Romiapex A-15 (Romidan, Kiryat Ono, Israel). The chemical-mechanical preparation of the channels was performed by the Reciproc system (VDW, Munich, Germany). After 15 days, the drilling was performed with Mineral Trioxide Aggregate (MTA) (Angelus, Londrina, PR, Brazil) and restoration of the region with Maxxion $R$ Glass lonomer Cement (FGM, Joinvile, SC, Brazil) (figure 2). As the fistula did not regress, a re-instrumentation of conduits and intracanal medication (IM) based on CHX 2\% and HC were performed. 


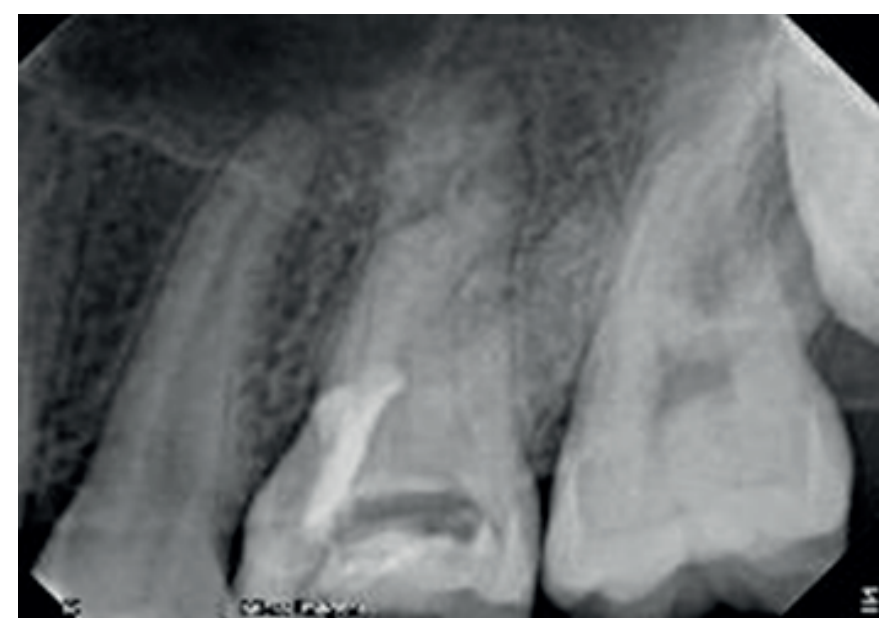

Figure 2. MTA insertion in drilling.

In the third session, with a persistent fistula, a new $\mathrm{Ml}$ exchange was performed, this time using the combination of lodoforn (Biodynamic, Ibiporã, PR, Brazil), HC (Biodynamic, Ibiporã, PR, Brazil) and CHX the aim of increasing the antimicrobial action of MI. In a fourth session, it was observed that the fistula was still present and the Ml was replaced, using the same combination of medications from the previous session for another attempt to regress the fistula.

In the fifth session, due to the persistence of the fistula, it was decided to perform the Photodynamic Therapy (PDT) with the Laser Duo (MMO, São Carlos, SP, Brazil) at $660 \mathrm{~nm}$ red wavelength, 18J power, for 180 seconds in each conduit, using $0.05 \%$ methylene blue with photosensitizer (figure 3). Subsequently, the irrigation of the conduits with saline solution was performed to remove the dye and placed new IM with $\mathrm{CHX} 2 \%$ and $\mathrm{HC}$.

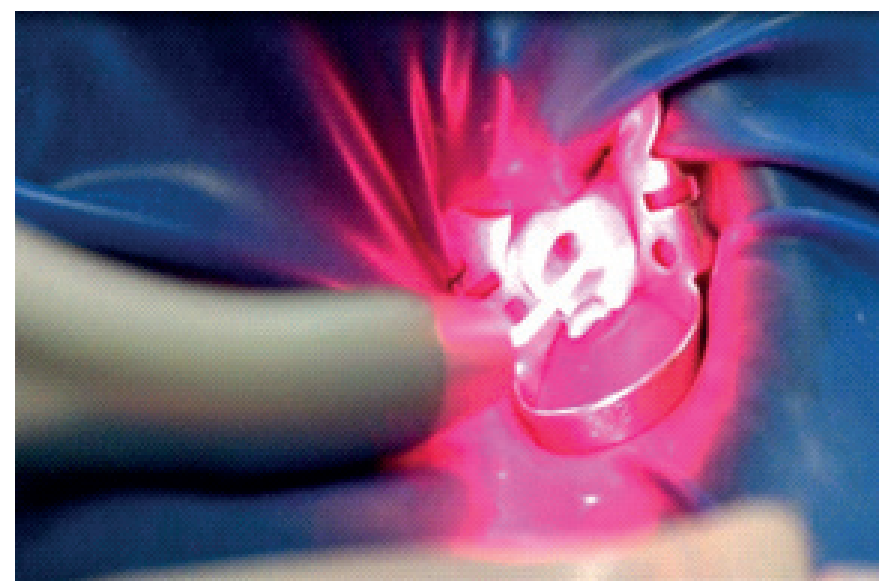

Figure 3. Execution of photodynamic therapy.
After 30 days, the patient returned to the clinic and the fistula regression was verified after the use of the laser and the obturation was performed, using the Hybrid Thermomechanical technique of Tagger, using Guta Condensor McSpadden (Maillefer, Ballagues, Switzerland), gutta-percha cones (Odous de Deus, BH, Brazil) and sealer sealer 26 (Dentsply, RJ, Brazil) (figure 4).

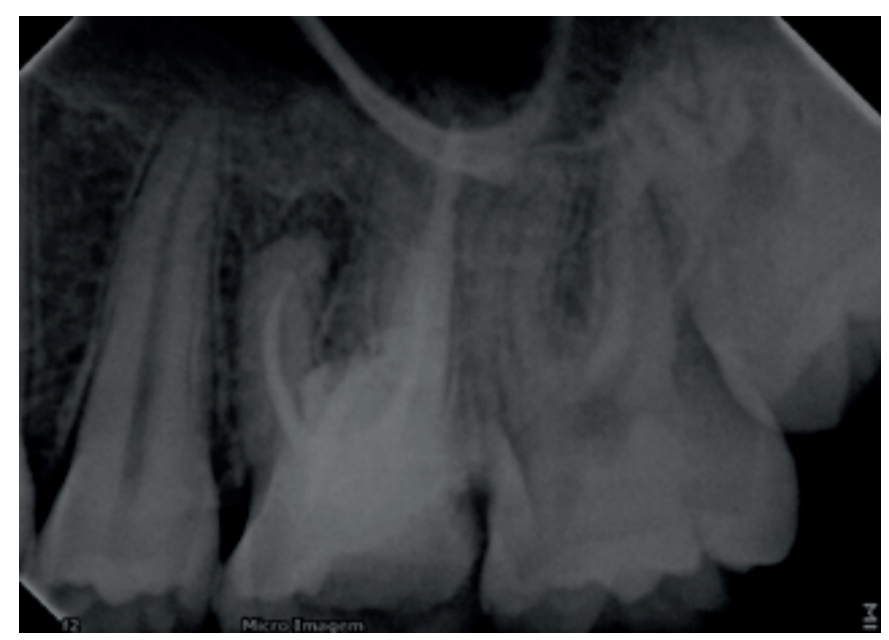

Figure 4. Radiographic appearance after obturation of the ducts.

After 30 days of obturation of the conduits, an evaluation was performed and a suitable sealing of the drilling region was observed radiographically, as well as the absence of symptomatology. The proservation was performed after one year, where bone neoformation was observed in the perforation region and absence of symptomatology (figure 5).

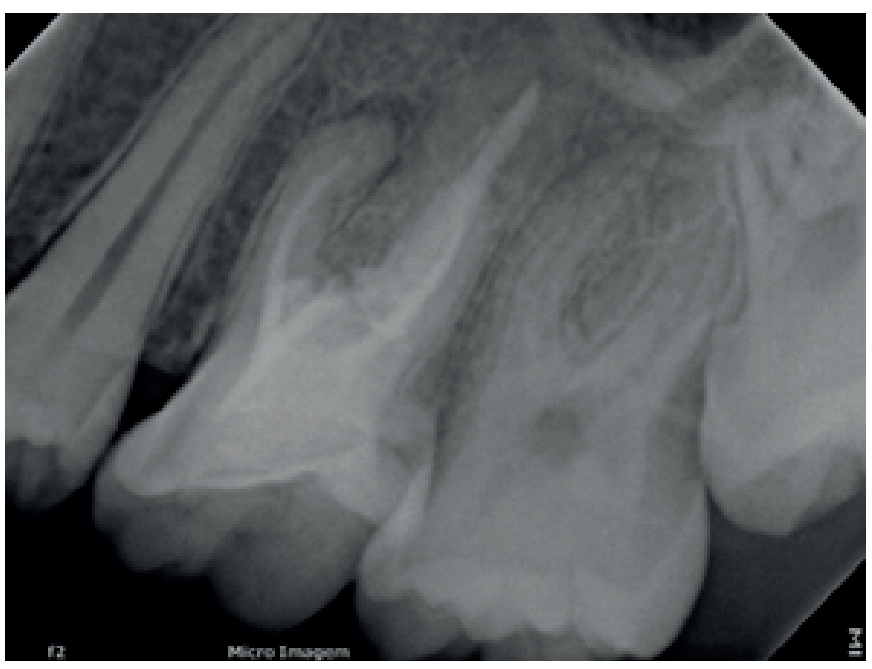

Figure 5. Radiography after 1 year of preservation. 
The described patient allowed the publication of this case report by signing the Term of Free and Informed Consent.

\section{DISCUSSION}

This work reported a case with apical periodontitis with persistent fistula in a tooth with pulp necrosis in which Photodynamic Therapy was used as an additional resource in the elimination of RCS microorganisms. The microorganism E. faecalis has been the most prevalent species in cases of endodontic failure, being resistant to most IM and to the chemical-mechanical preparation [13]. It is a facultative anaerobic that has been evidenced in approximately $77 \%$ of the cases, representing a threat to the success of the treatment. This is associated with resistance against the bactericidal effects of the most commonly used antimicrobial agents such as sodium hypochlorite $(\mathrm{NaOCI})$, $\mathrm{CHX}$ and HC [14]. Therefore, many studies concerning the efficiency of PDT refer to the elimination of this SCR microbial agent.

Recent studies have demonstrated that PDT is effective in decreasing cell viability of microbial cells and microbial biofilms and may be an important adjunct to the conventional technique for the treatment of various diseases in the dental context [9].

Several researches have been carried out to establish protocols for the use of PDT in relation to light parameters, exposure time and types of photosensitizers $[12,13]$. However, there is still no consensus on a standard protocol [9]. The protocol used in the clinical case included the $0.05 \%$ methylene blue associated with a low-power red laser that irradiated each conduit for 180 seconds according to the recommendations of the manufacturer of the Laser Duo (MMO, São Carlos, SP, Brazil) for its use in Endodontics.

Several authors suggest that PDT is a safe and quick process of killing cells [4]. According to Singh et al. [1], this therapy works to reduce the microbial load of RCS, as well as to improve dentin stability, provided there is a combination of an effective photosensitizer, adequate wavelength of light and ambient oxygen for its disinfecting action.

With regard to the photosensitizers, essential to the process of photodynamic therapy, Silva et al. [15], after an experimental study using methylene blue and malachite green at different irradiation time periods, concluded that both are effective as photosensitizers in the process of destruction of E. faecalis during PDT. In the case reported, methylene blue, one of the most cited dyes in the literature, was chosen for the application of the technique. The photosensitizers that have been widely used in PDT research are those derived from phenothiazines. Phenothiazines are tricyclic heteroaromatic compounds, blue dyes, such as methylene blue dye and toluidine blue, chlorines and forphirins $[4,13]$.

According to Garcez et al. [16], after a longitudinal study, PDT is a valuable aid in surgical endodontic treatment because it acts in reducing the bacterial load and cures the periapical lesion, which justifies its use as a therapeutic resource in the attempt to eliminate residual bacteria in RCS, so its use in the case reported, since after the mechanical chemical preparation and successive changes in $\mathrm{Ml}$ there was no regression of the fistula, a sign of endodontic infection.

It is worth noting that, according to Tennert et al. [17] and Bumb et al. [18], PDT cannot replace irrigation during the chemical preparation of the canals, being only an effective supplement in the disinfection of root canals, especially in cases of endodontic retreatment. Advances in root canal disinfection using new technologies and based on recent studies can improve the ability to disinfect the root canal system. However, conventional methods are still useful for obtaining a good prognosis [2].

In the case reported, PDT was of great importance for the clinical success of endodontic treatment, corroborating with all the cited studies, since, after its use as an alternative to reduce the microorganisms present in the RCS, there was remission of the fistula which persisted after mechanized instrumentation and successive $\mathrm{Ml}$ changes. Twelve months after treatment, the tooth was asymptomatic, with absence of fistula and radiographically without periapical lesion that may indicate failure of endodontic treatment associated with PDT.

\section{CONCLUSION}

Based on the methodology used in this study and considering its results, it can be concluded that the PDT proved to be efficient as a complementary therapy to the endodontic treatment in reducing the microbial load of the RCS, favoring the tissue repair and the remission of the signs and symptoms. 
Collaborators

SP LIMA, final approval of the version to be published. MS SILVA, also revising it critically for important intellectual contente. Participated in the review of the written part of the article and the final approval of the version to be published. ET SOUSA, Participated in the orientation and execution of the clinical case. He was responsible for the bibliographical research, writing of the article and co-interpretation of data. Also revising it critically for important intellectual content. Final approval of the version to be published. MO MELO, also revising it critically for important intellectual content. Resizing and with final approval of the version to be published.

\section{REFERENCES}

1. Singh S, Nagpal R, Manuja N, Tyagi SP. Photodynamictherapy: an adjunctto conventional root canal disinfection strategies. Aust Endod J. 2015;41(1): 54-71. http://dx.doi.org/10.1111/aej. 12088

2. Mohammadi Z, Jafarzadeh $H$, Shalavi S, Palazzi F. Recent advances in root canal disinfection: a review. Iran Endod J. 2017;12(4):402-406. http://dx.doi.org/10.22037/iej.v12i4.17 935

3. Torabinejad M, Handysides R, Khademi AA, Bakland LK. Clinical implications of the smear layer in endodontics: a review. Oral Surg Oral Med Oral Pathol Oral Radiol Endod. 2002; 94(6):658-66. http://dx.doi.org/10.1067/moe.2002.128962

4. Lacerda MFLS, Alfenas CF, Campos CN. Terapia fotodinâmica associada ao tratamento endodôntico - revisão de literatura. RFO. 2014;19(1):115-120. http://dx.doi.org/10.5335/rfo.v19i1. 3600

5. Bolhari B, Pourhajibagher M, Bazarjani F, Chiniforush N, Rad MR, Pirmoazen S, et al Ex vivo assessment of synergic effect of chlorhexidine for enhancing antimicrobial photodynamic therapy efficiency on expression patterns of biofilmassociated genes of Enterococcus faecalis. Photodiagnosis Photodyn Ther. 2018;22:227-232. http://dx.doi.org/10.1016/j. pdpdt. 2018. 04.019

6. Hamblin MR, Hasan T. Photodynamic therapy: a new antimicrobial approach to infectious disease? Photochem Photobiol Sci. 2004; 3(5):436-50. http://dx.doi.org/10.1039/ b311900a

7. Cieplik F, Tabenski L, Buchalla W, Maisch T. Antimicrobial photodynamic therapy for inactivation of biofilms formed by oral key pathogens. Front Microbiol. 2014 Aug 12;5:405. http://dx.doi.org/10.3389/fmicb.2014.00405

8. Masuda Y, Sakagami H, Horiike M, Kadokura H, Yamasaki T, Klokkevold PR, et al. Photodynamic therapy with pyoktanin blue and diode laser for elimination of enterococcus faecalis. In Vivo. 2018;32(4):707-712. http://dx.doi.org/10.21873/invivo. 11298
9. Carrera ET, Dias HB, Corbi SCT, Marcantonio RAC, Bernardi ACA, Bagnato VS, et al. The application of antimicrobial photodynamic therapy (aPDT) in dentistry: a critical review. Laser Phys. 2016 Dec;26(12). pii: 123001. http://dx.doi.org/10. 1088/1054-660X/26/12/123001

10. Chiniforush N, Pourhajibagher M, Shahabi S, Kosarieh E, Bahador A. Can antimicrobial photodynamic therapy (apdt) enhance the endodontic treatment? J Lasers Med Sci. 2016 Spring;7(2):76-85. http://dx.doi.org/10.15171/jlms.2016.14

11. Sebrão CC, Bezerra $A G J$ r, de França PH, Ferreira LE, Westphalen VP. Comparison of the Efficiency of Rose Bengal and Methylene Blue as Photosensitizers in Photodynamic Therapy Techniques for Enterococcus faecalis Inactivation. Photomed Laser Surg. 2017 Jan;35(1):18-23. http://dx.doi. org/10.1089/pho.2015.3995

12. Oliveira BP, Aguiar CM, Câmara AC. Photodynamic therapy in combating the causative microorganisms from endodontic infections. Eur J Dent. 2014;8:424-30. http://dx.doi.org/10.41 03/1305-7456.137662

13. Amaral RR, Amorim JCF, Nunes E, Soares JA, Silveira, FF. Terapia fotodinâmica na endodontia: revisão de literatura. RFO. 2010;15(2):207-11. http://dx.doi.org/10.5335/rfo. v15i2. 1347

14. Santos MGC, Brito LNS, Neves LEM, Azevedo MS, Santos TKG. Análise do uso da terapia fotodinâmica no tratamento endodôntico com base em um Congresso Odontológico. RFO. 2017;22(1): 49-53. http://dx.doi.org/10.5335/rfo.v22i1.7008

15. Silva EJ, Coutinho-Filho WP, Andrade AO, Herrera DR, Coutinho-Filho TS, Krebs RL. Evaluation of photodynamic therapy using a diode laser and different photosensitizers against enterococcus faecalis. Acta Odontol Latinoam. 2014;27(2):63-5. http://dx.doi.org/10.1590/\$1852-48342014 000200003

16. Garcez AS, Arantes-Neto JG, Sellera DP, Fregnani ER. Effects of antimicrobial photodynamic therapy and surgical endodontic treatment on the bacterial load reduction and periapical lesion healing. Three years follow up. Photodiagnosis Photodyn Ther. 2015 Dec;12(4):575-80. http://dx.doi.org/10.1016/j. pdpdt.2015.06.002

17. Tennert C, Feldmann K, Haamann E, Al-Ahmad A, Follo $M$, Wrbas KT, et al. Effect of photodynamic therapy (PDT) on Enterococcus faecalis biofilm in experimental primary and secondary endodontic infections. BMC Oral Health. 2014;14:132. http://dx.doi.org/10.1186/1472-6831-14-132

18. Bumb SS, Bhaskar DJ, Agali CR, Punia H, Gupta V, Singh V, et al. Assessment of Photodynamic Therapy (PDT) in disinfection of deeper dentinal tubules in a root canal system: an in vitro study. J Clin Diagn Res. 2014;8(11):ZC67-71. http://dx.doi. org/10.7860/JCDR/2014/11047.5155

Received on: 14/2/2018 Final version resubmitted on: 31/10/2018 Approved on: 6/12/2018 